\title{
Investigation of harvest index influenced by agrotechnical and botanical factors in hairy vetch (Vicia villosa Roth.)
}

\author{
Edit Kosztyuné Krajnyák ${ }^{1,2}$ - Béla Szabó ${ }^{1}$ - Sándor Vágvölgyi ${ }^{1}$ - Péter Pepó ${ }^{2}$ \\ ${ }^{1}$ University of Nyíregyháza, Institute of Engineering and Agricultural Sciences, Department of Agricultural Sciences and Environmental \\ Management, H-4400 Nyíregyháza, Sóstói Str. 31/b. \\ ${ }^{2}$ University of Debrecen, Kerpely Kálmán Doctoral School, H-4032 Böszörményi Str.138. Debrecen \\ krajnyak.edit@nye.hu
}

\begin{abstract}
SUMMARY
The biggest problem of Hungarian crop farming is mass production and the simple crop rotation based on cereals. There was a decrease in sowing area of protein crops which raises crucial issues in crop rotation and land use. Therefore, growing papilionaceous plants, which are now considered to be alternative plants, should be taken under close examination. Hairy vetch (Vicia villosa Roth.) belongs to the family of papilionaceous plants and it can be grown in light weak soils.

In Hungary, hairy vetch was used as green forage at first, but it later became a green manure plant. Nowadays, it is used as a cover crop and its sowing seed has a good export market. In low fertile soils it is able to produce a big amount of green yield (25-40 $t$ ha $\left.{ }^{-1}\right)$ even in spring while its seed yield could be 0.4-0.5 $t \mathrm{ha}^{-1}$ at farm level. In addition to its morphological characteristics hairy vetch is grown mainly with a supporting plant, i.e. triticale in many cases.

Our purpose was to test the harvest index and its agrotechnical and botanical factors of hairy vetch in different cropping systems.
\end{abstract}

Keywords: hairy vetch; triticale; harvest index; mixed-cropping; strip copping

\section{INTRODUCTION}

In Europe, hairy vetch was first produced in Germany in the middle of the $19^{\text {th }}$ century (Hanelt, 2001). Its original home is Asia Minor. It is an annual, overwintering species, general all over in Europe from the Mediterranean sea to the Scandinavian peninsula. Its domestic variety came from North-Caucasus to Carpathian basin in the $19^{\text {th }}$ century (Késmárki, 2005).

In Hungary its cultivation started only in the end of 1800 years mainly for green forage. Nowadays, it is grown as green manure and cover crop (Gondola and Szabóné, 2010). The biggest problem of Hungarian plant growing is the mass production and the simple crop rotation based on cereals. The troubleshooting is hard because of the dramatic decrease in number of animals and homeland consumption. In the past few years there was a decrease in sowing area of protein crops which raises crucial issues concerning crop rotation and land use. Therefore, wide range of alternative plants should be taken under close examination in order to establish biodiversity (Lazányi, 2010.) Among alternative plants hairy vetch is considered to be a first plant of sand soils. (Antal et al., 1966).

Brown et al. (1993) found that hairy vetch which is a green manure crop is frequently used as a cover crop. It uses up only small amount of water and fixes nitrogen from the air. Therefore, as a previous crop is able to significantly increase the maize yield both in conventional and in no-tillage systems. Miko et al. (2012) found that biomass yield of green manure plants and their positive effect on soil fertility, under unfavourable ecological conditions, can be increased by adding $50 \mathrm{~kg} \mathrm{ha}^{-1}$ nitrogen. Newly incorporation of green manure plants causes inadequate off-spring and slow early developing of after-crop. Therefore, 4-6 weeks should be kept between the incorporation and sowing. (Westsik, 1936; Ballenegger et al., 1936). Kahnt (1986) recommended the green manure application to farms where cereals are prevalent in crop rotation; nitrogen fertilizing is not intended or not possible. The group of green manure plant could be divided into two groups, papilionaceous and all the others. Papilionaceous are applied owing to nitrogen fixing ability of symbionta Rhizobium species while the others are applied due to their other favourable agronomic properties.

According to Dobránszki (2002) green yield of hairy vetch could be $25-45 \mathrm{t} \mathrm{ha}^{-1}$, while its seed yield could be $500-800 \mathrm{~kg} \mathrm{ha}^{-1}$. Szabóné (2002) pointed out that hairy vetch is able to produce great amount of green yield in low fertile soil even in early spring. Seed yield potentially could be $1.5-2.0 \mathrm{t} \mathrm{ha}^{-1}$, at farm level it is $0.4-0.5 \mathrm{t} \mathrm{ha}^{-1}$. As for green yield $25-30 \mathrm{t} \mathrm{ha}^{-1}$ is reachable. Gondola and Szabóné (2010) reported that hairy vetch sowing seed has a good export market. Based on FAO data (Table 1) green yields vary between 4 and $63 \mathrm{t} \mathrm{ha}^{-1}$, seed yields changes between 0.444 and $1.39 \mathrm{t} \mathrm{ha}^{-1}$.

Lazányi (1994) found that Hungary’s ecological conditions give good opportunities to vetch seed production. As excellent green yield was reached with cultivar "Kisvárdai" in Germany, its sowing seed has a good market. This cultivar due to its favourable agronomic properties was registered in Germany under the mane of "Hungvillosa" in 1980.

Harvest index was first calculated to cereals and legumes in India, Western Europe and the USA and proved to be less useful for maize and tuber crops. Harvest index of modern cereal cultivars in high input farming systems is between 0.4 and 0.6 , and is an important parameter in plant growing (Donald and 
Hamblin, 1976) calculated as seed yield divided with total above-ground yield (Donald, 1968).

Table 1. Changes in yield (seed and green mass yield) and growing area of vetch species in Hungary between 2008 and 2017

\begin{tabular}{cccc}
\hline Years & $\begin{array}{c}\text { Growing area } \\
\text { (ha) }\end{array}$ & $\begin{array}{c}\text { Seed yield } \\
\left(\mathbf{t ~ h a}^{-\mathbf{1}}\right)\end{array}$ & $\begin{array}{c}\text { Green yield } \\
\left(\mathbf{t ~ h a}^{-\mathbf{1}}\right)\end{array}$ \\
\hline 2008 & 18 & 1.3889 & 25 \\
2009 & 26 & 0.9615 & 25 \\
2010 & 65 & 0.9692 & 63 \\
2011 & 0 & 0 & 0 \\
2012 & 9 & 0.4444 & 4 \\
2013 & 27 & 0.9040 & 24 \\
2014 & 36 & 0.8760 & 32 \\
2015 & 43 & 0.7786 & 33 \\
2016 & 47 & 0.7115 & 33 \\
2017 & 51 & 0.6564 & 33 \\
\hline Average & $\mathbf{3 2 . 2}$ & $\mathbf{0 . 7 6 9 1}$ & $\mathbf{2 7 . 2}$ \\
\hline
\end{tabular}

Source: http://www.fao.org/faostat

Vetch species have hypogeal germination (Jánossy, 1971). Its plumule elongates strongly and containing no chlorophyll. Later, leaf fundaments became green and emerge above the soil horizon. Pusztai et al (cit. Radics, 2012) says that hairy vetch develops strong root system with long side roots. It is climbing stems reach up to 1.5 $\mathrm{m}$ in height. Its stem is rectangular, ramified and procumbent. Its paripinnate compound leaves ending in a ramified tendril, with 6-11 pairs of narrowly elliptical leaflets. Stipules are eglandular. Flowers are middle in size; petals are blueish violet or purple sometimes white in colour. Calyx is short and dented, gibbous at the base. The pods are narrow, flattened and naked being 3-8 seeds in them. Seeds are black $3 \mathrm{~mm}$ in diameter, with a matte, long-shaped or ellipsoid hilum. Thousand kernel weight is $18-35 \mathrm{~g}$.

Papilionaceous have favourable preceding crop effect due to nitrogen-fixing Rhizobium species living in root nodules (Vágvölgyi et al., 2018). Due to these bacteria hairy vetch is able to fix a large amount of nitrogen from the air. There are many different evaluations concerning nitrogen fixation, but vetch can fix $150 \mathrm{~kg} \mathrm{ha}{ }^{-1}$ nitrogen depending on weather conditions (Gondola and Szabóné, 2010).

Soil tillage should be adjusted to the needs of supporting plant, and should be started with stubblebreaking right after harvesting the preceding crop. (Radics, 2002). Its nutrient need is low. Vetch do not need nitrogen application, has a moderate phosphorus and microelement need but it makes return for higher phosphorus and potassium supply (Erhart, 1996).

According to Gondola and Szabóné (2010) optimal sowing time ranges from mid of September to end of September. Experimental results and farming practices bear clearly out the advantage of growing with supporting plants (wheat, triticale, rye) but for sowing seed purpose it could be grown solely. The suggested seed amount is $40-60 \mathrm{~kg} \mathrm{ha}^{-1}(1-1.5$ million seed) in sole cropping, and $35-40 \mathrm{~kg} \mathrm{ha}^{-1}(0.8-1.0$ million seed) in intercropping. The suggested sowing depth is $4-8$ $\mathrm{cm}$.

In soil of good agronomic conditions weeds cannot compete with hairy vetch although hard-to-control weeds need to be managed. Optimal harvesting time is the first part of July, when lower pods are ripen and the seeds could be touchable in them. Seed clearing, drying and de-weevilling is worth to be done at the same time with harvesting (Radics, 2002).

\section{MATERIALS AND METHODS}

Our field experiments were carried out in Training Farm of University of Nyíregyháza. The 250 hectare field located in Nyírtelek-Ferenctanya, where ecological farming (lacy phacelia, mustard, sunroot, lupin) is managed in 138 hectares, besides conventional crop growing. In 2018 our experimental site took place in nearly 12 hectare (Figure 1).

Figure 1. Experimental site

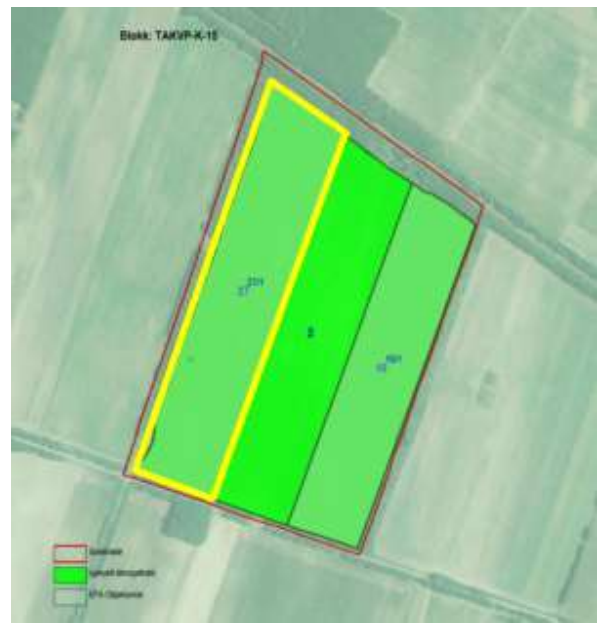

Source: https:/www.mepar.hu/mepar

Prior to setting up our experiments, soil samples were taken by Eijkelkamp tubular soil sampler from the depth of 0-30 cm. Soil analysis was done by Magyar Kertészeti Szaporítóanyag Nonprofit Kft. Talaj- és Növényvizsgáló Laboratórium (Table 2).

The soil is an acid, light (sandy silt texture) brown forest soil with alternating thin layers of clay substances having medium humus content. According to WRB it is called Lamellic Arenosol (Orthodystric) Previous crop was lacy phacelia. Cultivar of hairy vetch was Hungvillosa bred in Kisvárda. The valuable property of the variety is that it gives a large green mass on soils of low fertility early in the spring. It has a good overwintering, bushy and fertile ability. The supporting plant was the Titanium, triticale variety, which can be successfully grown on the fertile acidic sandy soils. Its yielding and tillering ability are excellent. Its height is moderate, its stem is strongly waxy. It is resistant to powdery mildew and yellow leaf foliage. 
Table 2. Results of soil analysis (2018)

\begin{tabular}{|c|c|}
\hline Parameter & Value \\
\hline Soil layer $(\mathrm{cm})$ & $0-30$ \\
\hline pH-KCI (-) & 4.67 \\
\hline Soil plasticity according to Arany $\left(\mathrm{K}_{\mathrm{A}}\right)$ & 33 \\
\hline Total water soluble salts $(\mathrm{m} / \mathrm{m} \%)$ & $<0.02$ \\
\hline $\mathrm{CaCO}_{3}(\mathrm{~m} / \mathrm{m} \%)$ & $<0.1$ \\
\hline Humus content $(\mathrm{m} / \mathrm{m} \%)$ & 1.78 \\
\hline $\mathrm{NO}_{3}^{-}-\mathrm{N}+\mathrm{NO}_{2}^{-}-\mathrm{N}\left(\mathrm{mg} \mathrm{kg}^{-1}\right)$ & 13.3 \\
\hline $\mathrm{SO}_{4}{ }^{2-}-\mathrm{S}\left(\mathrm{mg} \mathrm{kg}^{-1}\right)$ & $<50$ \\
\hline $\mathrm{Mg}\left(\mathrm{mg} \mathrm{kg}^{-1}\right)$ & 148 \\
\hline $\mathrm{P}_{2} \mathrm{O}_{5}\left(\mathrm{mg} \mathrm{kg}^{-1}\right)$ & 86.5 \\
\hline $\mathrm{K}_{2} \mathrm{O}\left(\mathrm{mg} \mathrm{kg}^{-1}\right)$ & 176 \\
\hline $\mathrm{Na}\left(\mathrm{mg} \mathrm{kg}^{-1}\right)$ & 74.7 \\
\hline $\mathrm{Zn}\left(\mathrm{mg} \mathrm{kg}^{-1}\right)$ & 0.93 \\
\hline $\mathrm{Cu}\left(\mathrm{mg} \mathrm{kg}^{-1}\right)$ & 4.01 \\
\hline $\operatorname{Mn}\left(\mathrm{mg} \mathrm{kg}^{-1}\right)$ & 212 \\
\hline
\end{tabular}

Soil was prepared for sowing in September. Shallow ploughing was followed by seedbed combination. Mixed cropping and strip cropping was applied. In mixed cropping $30 \mathrm{~kg}$ hairy vetch seed and $70 \mathrm{~kg}$ triticale seed was applied per hectare in the end of September. In order to avoid the seed segregation hopper of sowing-machine was filled with $100 \mathrm{~kg}$ mixed seed. Triticale and vetch were sawn in different rows. Ratio of triticale and vetch rows was $6: 2$ both in strip cropping and in mixed-cropping. Since our experiment was carried out in an ecological farm, no fertilizer or pesticides were applied. Plots were harvested in $1^{\text {st }}$ July 2019 . The $1 \mathrm{~m}^{2}$ size plots were set up in four repetitions. Plants at early ripen stage were dig out, bound and roots were washed. Dried plant samples were processed in Plant Growing Lab of University of Nyíregyháza. The above-ground biomass yields and grain yields were measured (Figure 2). Statistic evaluation was carried out by SPSS software.

Figure 2. Digging out, bounding and processing of plant samples
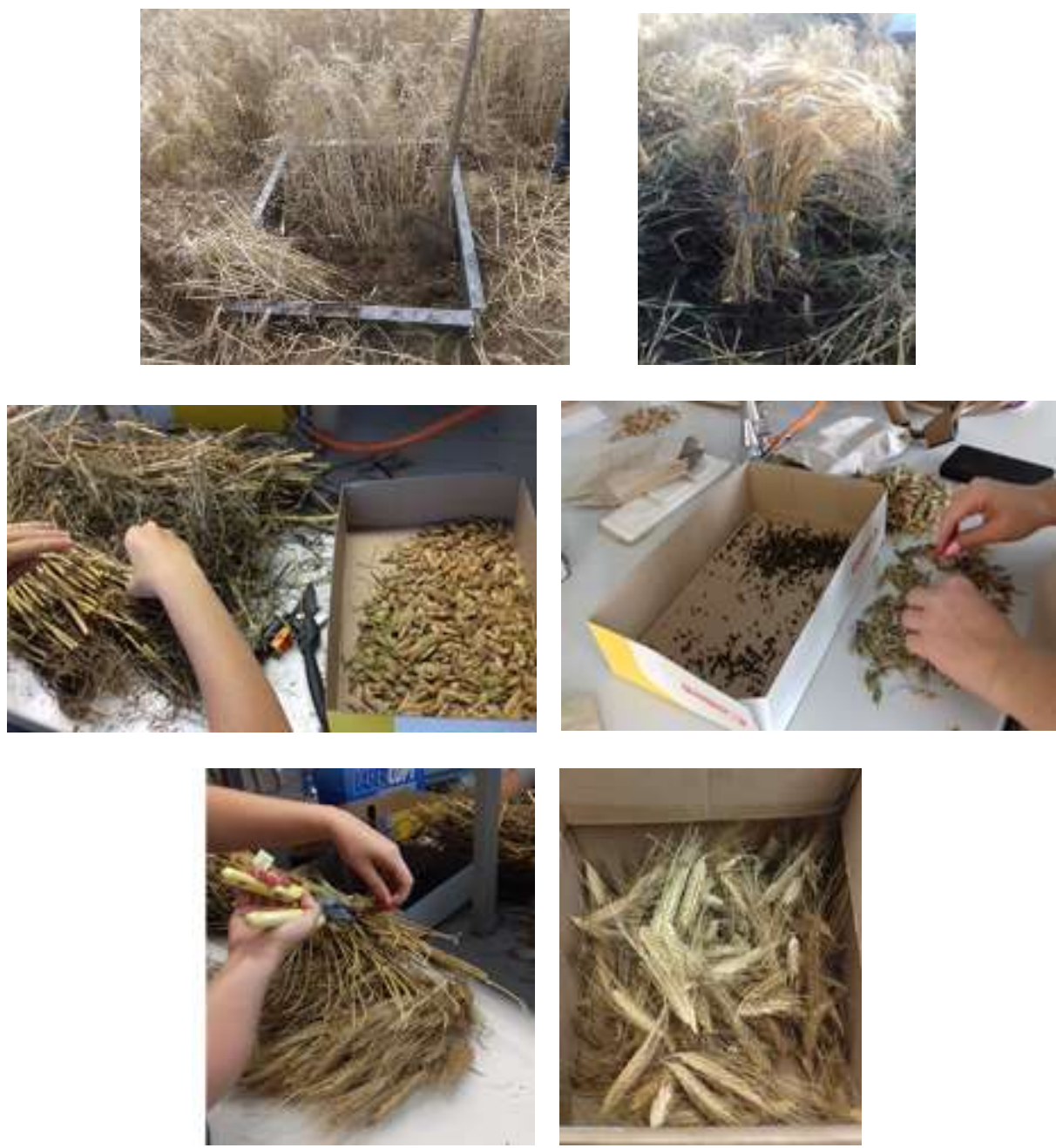

(Photo: Kosztyuné K., E.) 
The weather conditions of the experimental years are characterized by the precipitation and temperature data (Figures 3-4).

The meteorological data were recorded on the data of the DE AKIT Nyíregyháza Research Institute. The measured values are always compared to the 50 -year average. The precipitation from October to April was
$225.6 \mathrm{~mm}$ that is less than 50-year average and had a negative effect on early developing of hairy vetch greatly impeding rising and spring tillering. Under these circumstances shoot growing slowed down and only lower quantity of green biomass come off. Later, development of the stand speeded up due to the high amount of precipitation fallen in May and June.

Figure 3. Averages monthly precipitation data

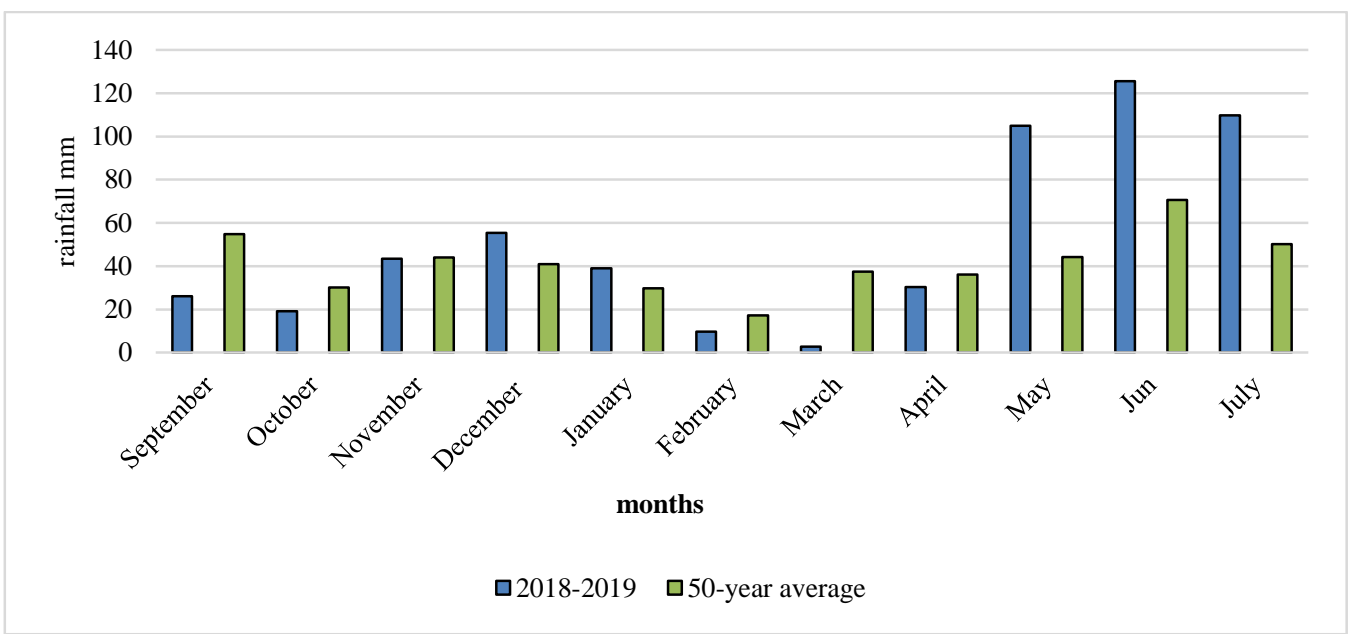

Source: measurements done by DE AKIT Nyíregyháza Research Institute

Figure 4. Average monthly temperature data

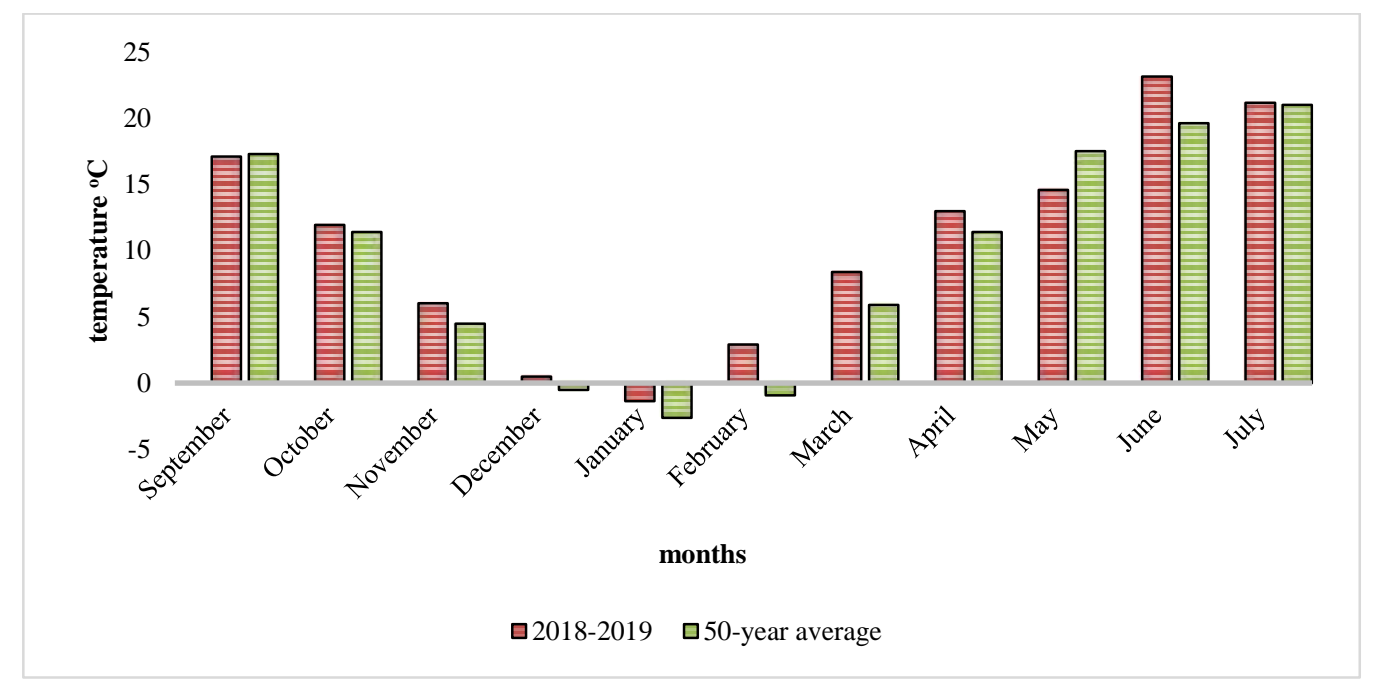

Source: DE AKIT Nyíregyháza Research Institute

At early developing stage of vetch air temperature was at around the 50-year average. In spring (from February to April) low precipitation and sudden up warming caused a remarkable water shortage.

\section{RESULTS AND DISCUSSION}

Data needed for counting the Harvest Index are showed in Table 3. In our experiments sole cropping means triticale, strip and mixed-cropping mean triticale plus hairy vetch stands. 
Table 3. Harvest index of hairy vetch and triticale in different cropping systems

\begin{tabular}{|c|c|c|c|c|c|}
\hline $\begin{array}{l}\text { Cropping system/ } \\
\text { repetition number }\end{array}$ & $\begin{array}{c}\text { Above-ground } \\
\text { biomass yield } \\
\text { kg m}^{-2} \\
\end{array}$ & $\begin{array}{c}\text { Triticale } \\
\text { kg m}^{-2}\end{array}$ & $\begin{array}{c}\text { Seed yield } \\
\text { Hairy vetch } \\
\text { kg m }^{-2} \\
\end{array}$ & $\begin{array}{c}\text { Total } \\
\mathbf{k g ~ m}^{-2} \\
\end{array}$ & Harvest index \\
\hline Sole cropping/I. & 0.4722 & 0.1955 & - & 0.1955 & 0.414 \\
\hline Sole cropping/II. & 0.4979 & 0.1845 & - & 0.1845 & 0.371 \\
\hline Sole cropping/III. & 0.6283 & 0.2750 & - & 0.2750 & 0.438 \\
\hline Sole cropping/IV. & 0.3491 & 0.1441 & - & 0.1441 & 0.413 \\
\hline Average & 0.4869 a & 0.1998 & - & 0.1998 a & $0.410 \mathrm{a}$ \\
\hline Strip cropping/I. & 0.5243 & 0.1705 & 0.0231 & 0.1936 & 0.369 \\
\hline Strip cropping/II. & 0.6350 & 0.2124 & 0.0322 & 0.2446 & 0.385 \\
\hline Strip cropping/III. & 0.5864 & 0.1726 & 0.0336 & 0.2062 & 0.352 \\
\hline Strip cropping/IV. & 0.6750 & 0.2544 & 0.0239 & 0.2783 & 0.412 \\
\hline Average & 0.6051 a & 0.2025 & 0.0282 & 0.2307 a & $0.380 \mathrm{a}$ \\
\hline Mixed cropping/I. & 0.3950 & 0.0964 & 0.0273 & 0.1237 & 0.313 \\
\hline Mixed cropping/II. & 0.4455 & 0.1378 & 0.0195 & 0.1573 & 0.353 \\
\hline Mixed cropping/III. & 0.6676 & 0.1683 & 0.0417 & 0.2100 & 0.315 \\
\hline Mixed cropping/IV. & 0.4092 & 0.1276 & 0.0211 & 0.1487 & 0.363 \\
\hline Average & $0.4792 \mathrm{a}$ & 0.1325 & 0.0274 & 0.1599 a & 0.333 b \\
\hline
\end{tabular}

Different letters means significant differences at $\mathrm{p}<0.1$ level.

Strip cropping reveals the highest above-ground biomass yield and the highest total seed yield. Harvest index of triticale cultivated in sole cropping was higher than that of in strip cropping and in mix-cropping. Differences between sole cropping and strip cropping were not significant. Nevertheless, differences between sole cropping and mixed cropping, and differences between strip cropping and mixed cropping were significant $(\mathrm{p}$-value $=0.037)$ at $\mathrm{p}<0.1$ level. Biomass yield components are showed in Table 4.

Table 4. Components of hairy vetch and triticale biomass yield under different cropping systems

\begin{tabular}{|c|c|c|c|c|c|}
\hline $\begin{array}{l}\text { Cropping system/ } \\
\text { repetition number }\end{array}$ & $\begin{array}{l}\text { Root yield } \\
\mathrm{kg} \mathrm{m}^{-2}\end{array}$ & $\begin{array}{l}\text { Stem yield } \\
\mathrm{kg} \mathrm{m}^{-2}\end{array}$ & $\begin{array}{l}\text { Grain yield } \\
\text { kg m}^{-2}\end{array}$ & $\begin{array}{l}\text { Pulse seed yield } \\
\qquad \mathrm{kg} \mathrm{m}^{-2}\end{array}$ & $\begin{array}{c}\text { Above-grouond } \\
\text { biomass yield } \\
\mathrm{kg} \mathrm{m}^{-2}\end{array}$ \\
\hline Sole cropping/I & 0.2393 & 0.1930 & 0.2792 & - & 0.4722 \\
\hline Sole cropping/II & 0.2098 & 0.1938 & 0.3041 & - & 0.4979 \\
\hline Sole cropping/III & 0.2579 & 0.2427 & 0.3856 & - & 0.6283 \\
\hline Sole cropping/IV. & 0.1844 & 0.1491 & 0.2000 & - & 0.3491 \\
\hline Average & 0.2229 & 0.1947 & 0.2922 & - & 0.4869 \\
\hline Strip cropping/I & 0.1814 & 0.2404 & 0.2458 & 0.0381 & 0.5243 \\
\hline Strip cropping/II & 0.2184 & 0.2768 & 0.3129 & 0.0453 & 0.6350 \\
\hline Strip cropping/III & 0.2020 & 0.2764 & 0.2550 & 0.0550 & 0.5864 \\
\hline Strip cropping/IV & 0.2403 & 0.2670 & 0.3730 & 0.0350 & 0.6750 \\
\hline Average & 0.2105 & 0.2651 & 0.2966 & 0.0434 & 0.6051 \\
\hline Mixed cropping/I & 0.1323 & 0.2021 & 0.1479 & 0.0450 & 0.3950 \\
\hline Mixed cropping/II & 0.1614 & 0.1980 & 0.2162 & 0.0313 & 0.4455 \\
\hline Mixed cropping/III & 0.1269 & 0.3349 & 0.2670 & 0.0657 & 0.6676 \\
\hline Mixed cropping/IV & 0.1825 & 0.1831 & 0.1918 & 0.0343 & 0.4092 \\
\hline Average & 0.1508 & 0.2295 & 0.2057 & 0.0441 & 0.4792 \\
\hline
\end{tabular}

The highest root yield was measured in sole cropping followed by strip cropping and mixedcropping. However, the lowest stem yield was observed in sole cropping. Grain yield in sole cropping and in strip cropping reveals almost the same value. Pulse seed yield in strip cropping and mixed-cropping was almost the same. Strip cropping reveals the highest above-ground biomass yield, and apart from root yield it showed higher figures in all the biomass yield components than sole cropping.

\section{CONCLUSIONS}

From our results we can conclude that there were no significant differences between the harvest indexes of sole and strip cropping. Harvest index in sole and strip 
cropping was significantly higher than in mixed cropping. As for above-ground biomass yields and seed yields there were no significant differences between the cropping systems. When data are evaluated it should be taken into account that cropping was carried out under extreme ecological circumstances.

\section{ACKNOWLEDGEMENTS}

The project was supported by the European Union cofinanced by European Social Fund in the framework of EFOP-3.6.2-16-2017-00001 "Research of complex rural-economical and sustainable developments, and drawing up its service-related network in the Carpathian basin".

\section{REFERENCES}

Ashofteh Beiragi, M.-Khavari Khorasani, S.-Sarmad Nabavi, M.Nikzad Antal, J.-Egerszegi, S.-Penyigei, D. (1966): Növénytermesztés homokon. Mezőgazdasági Kiadó. Budapest.

Ballenegger, R.-Bittera, M.-Csiky, J.-Dicenty, D.-Halács, Á.Villax, Ö.-Zucker, F. (1936): A talaj termőerejének fenntartásáról és a műtrágyázásról. Az Országos Mezőgazdasági Kamara Talajtani és Műtrágyázási Osztályának Kiadványai. 8. szám. Budapest.

Brown, R.E.-Varvel, G.E.-Shapiro, C.A. (1993): Residual effects of interseeded hairy vetch on soil nitrate-nitrogen levels. Soil Science Society of America Journal. 57. 121-124.

Dobránszki， J. (szerk.) (2002): A szöszösbükkönytermesztés technológiája. In: A Nyírségi burgonyatermesztés fejlesztése. homokhasznosítás tájba illő növényekkel. Nyíregyháza 206214.

Donald, C.M. (1962): In search of yield. Journal of the Australian Institute of Agricultural Sciences 28. 171-178.

Donald, C.M. (1968): The breeding of crop ideotypes. Euphytica 17. 385-403.

Donald, C.M.-Hamblin, J. (1976): The biological yield and harvest index of cereals as breeding agronomic and plant criteria. Advances in Agronomy 28. 361-405.

Erhart, D.R (1996): Managing soil phosphorus accumulation from poultry litter application through vegetablae/legume rotations. Project report LS95-69. Southern Region SARE. Griffin. Ga. in: Clark, A. (2007) (Ed) Managing cover crops profitably. $3^{\text {rd }} \mathrm{ed}$. Sustainable Agriculture Network handbook series. bk 9. p. 248.

Food and Agriculture Organization of the United Nations (FAOSTAT) - www.fao.org/faostat

Gondola, I.-Szabóné, Cs.K. (2010): Szöszösbükköny (Vicia villosa Roth.). In: Gondola: Az alternatív növények szerepe az Északalföldi Régióban. Nyíregyháza.131-151.

Hanelt, P. (2001): Mansfeld's Encyclopedia of Agricultural and Horticultural Crops. Institute of Plant Genetics and Crop Plant Research. Original German edition published by Akademie Verlag. Berlin an Springer-Verlag. Berlin Heidelberg New York. 1986. p. 3700.
Jánossy, A. (1971): A vicia-fajok termesztése és nemesítése. Bükkönytermesztés. In: Mándi, Gy. (Ed) A Vicia fajok termesztése és nemesítése. Akadémia Kiadó. Budapest.

Kahnt, G. (1986): Zöldtrágyázás. Mezőgazdasági Kiadó. Gödölló. 265-275.

Késmárki, I. (2005): Takarmánynövények.. Maghozó szöszös bükköny. In: Antal, J.: Növénytermesztéstan 2. Mezögazda Kiadó. Budapest. 453-456.

Lazányi, J. (1994): Homokjavító vetésforgókkal végzett kísérletek eredményei. DATE Kutató Központ. Nyíregyháza. 1-238.

Lazányi, J. (2010): Szabolcs-Szatmár- Bereg megyében nemesített alternatív növények helyzete és jelentősége. In: Gondola (szerk): Az alternatív növények szerepe az Észak-alföldi Régióban. 2775.

Mikó. P.-Kovács, G.-Balla, I.-Vasa, L.-Gyuricza, Cs. (2012): Investigation of the Biomass and Nutrient Content of Green Manuring Plants as Second Crops in Hungary. Notulae Botanicae Horti Agrobotanici Cluj-Napoca. 40. 1. 47-52.

Pusztai, P.-Kuroli, G.-Németh, L.-Reisinger, P.-Csathó, P.Árendás, T.-Németh, T.-Fodor, N. (2012): Bükköny. In: Radics, L. (Szerk.) Fenntartható szemléletủ szántóföldi növénytermesztéstan 3. 63-75.

Radics, L. (2002): Alternatív növények termesztése II. Szaktudás Kiadó Ház. Budapest. 54-60.

Szabóné Csalló, K. (2002): Szöszösbükköny (Vicia Villosa Roth.) In: Iszályné (szerk.) Növénynemesítés és fajtafenntartás a Debreceni Egyetem Kutató Központjában. Nyíregyháza. 80-88.

Vágvölgyi, S.-Szabó, B.- Kosztyuné, K.E. (2018): A pillangósvirágú takarmánynövények jelentősége a savanyú homoktalajok fenntartható hasznosításában. In: Hangsúlyok a térfejlesztésben. (Szerk. Nagy, J.) 399-409.

Westsik, V. (1936): Homoki gazda. „Pátria“ Irodalmi Vállalat és Nyomdai Részvénytársaság. Budapest. 